\title{
Memperbaiki Kemampuan Argumentasi Siswa Kelas XI melalui Teknik Bertanya Guru dan Argumentative Assessment
}

\section{Improving Students' Argumentation Skill by using Teachers' Questioning Technique and Argumentative Assesment}

\author{
TIRSA PUTRI KRISTIANI ${ }^{1 *}$ \\ ${ }^{1}$ Pendidikan Biologi, Fakultas Keguruan dan Ilmu Pendidikan, Universitas Sebelas Maret. J1. Ir. Sutami No.36A, Jebres, Kota \\ Surakarta, Jawa Tengah 57126 \\ *Corresponding authors: First.Author@institution.org
}

Manuscript received: ......... Revision accepted:

\begin{abstract}
Argumentasi merupakan tujuan utama dari pendidikan sains karena dapat melibatkan siswa dalam praktik sains yang kompleks di mana siswa menggagas dan menjustifikasi klaim pengetahuan. Penelitian bertujuan untuk mengetahui perubahan kemampuan argumentasi siswa kelas XI setelah penerapan teknik bertanya guru dan argumentative assessment. Penelitian dilaksanakan selama tiga siklus dengan teknik teknik bertanya guru dan argumentative assessment. Subjek penelitian adalah kelas XI MIPA berjumlah 36 siswa yang dipilih berdasarkan metode purposive sampling. Siswa dibagi menjadi dua kelompok, Low achievement dan High achievement berdasarkan hasil belajar tengah semester. Data yang dianalisis adalah pertanyaan yang disampaikan guru kepada siswa, respon siswa terhadap pertanyaan guru dan hasil jawaban siswa terhadap argumentative assessment yang diberikan guru. Analisis data menggunakan rubrik penilaian level argumentasi yang dikembangkan oleh Osborne, Erduran, \& Simon dan modifikasi peneliti dengan skoring level argumentasi. Hasil penelitian menunjukkan adanya perubahan dan peningkatan kemampuan argumentasi siswa setalah diterapkan teknik bertanya guru dan argumentative assessment. Perubahan yang ditunjukkan adalah siswa mampu mengemukakan evidence dan reasoning. Siswa yang termasuk dalam Low achievement dan High achievement mengalami perubahan dalam berargumentasi.
\end{abstract}

Keywords: argumentasi, teknik bertanya guru, argumentative assessment

\section{PENDAHULUAN}

Argumentasi merupakan tujuan utama dari pendidikan sains karena dapat melibatkan siswa dalam praktik sains yang kompleks di mana siswa menggagas dan menjustifikasi klaim pengetahuan (McNeill \& Berland, 2010). Argumentasi merupakan kegiatan eksplorasi sistematis dari konfrontasi teoritis melalui koordinasi antara bukti-bukti yang menggambarkan hasil observasi empiris atau hasil eksperimen tentang fenomena alam (Bell \& Linn, 2000). Argumentasi adalah praktek penting dalam IPA, para ilmuwan secara sosial mengembangkan pengetahuan dengan cara mengevaluasi klaim ilmiah, mempertimbangkan bukti dan menaksir penjelasan alternatif (McNeill \& Berland, 2010). Argumentasi merupakan proses mengumpulkan berbagai komponen yang dibutuhkan untuk membangun suatu argumen (Osborne et al., 2004). Indikator argumentasi berupa komponen-komponen argumentasi Toulmin (1958) direduksi oleh Krajcik \& McNeill (2011) supaya sesuai dengan kemampuan siswa dan menghasilkan 4 komponen argumentasi, yaitu: claim, evidence, reasoning, dan rebuttal. Claim merupakan suatu gagasan, kesimpulan, hipotesis, atau pendapat terhadap suatu kejadian atau fenomena (Kaya, Erduran, \& Cetin, 2010). Evidence merupakan bukti yang digunakan untuk mendukung claim. Reasoning merupakan alasan yang diberikan untuk menghubungkan evidence dengan claim. Rebuttal merupakan alternatif jawaban untuk menolak claim, karena claim yang diberikan dianggap kurang tepat (Krajcik \& McNeill, 2011).

Berdasarkan hasil pengamatan awal, siswa terlihat pasif saat pembelajaran, hanya memperhatikan materi yang disampaikan oleh guru dan beberapa siswa mencatat materi. Siswa hanya memberi jawaban serentak dan jawaban singkat tanpa didukung bukti maupun alasan. Siswa tidak terbiasa dalam menyampaikan pendapat tentang materi yang sedang dipelajari. Faktor yang mempengaruhi kurangnya kemampuan argumentasi siswa adalah kebiasan guru yang masih mendominasi pembelajaran. Pertanyaan yang diberikan guru kepada siswa tidak mendorong siswa untuk menyampaikan pendapat. Soal evaluasi yang diberikan guru juga tidak melatihkan siswa untuk berargumentasi. Guru biasa meminta siswa untuk menghafalkan salah satu konsep pada materi yang dianggap penting bukan mendiskusikan materi yang sedang dipelajari.

Argumentasi dalam pembelajaran mendukung proses kognitif dan metakognitif siswa, dan mendukung penalaran siswa (Alexiandre \& Erduran, 2008). Argumentasi siswa dapat dilatih melalui bagaimana cara guru menyampaikan pertanyaan-pertanyaan saat pembelajaran berlangsung. Dari delapan keterampilan dasar mengajar, keterampilan bertanya merupakan keterampilan yang mendominasi dalam pembelajaran karena dengan pertanyaan dapat mendukung keterampilan dasar yang lain (Ermasari, 
Subagia, \& Sudria, 2014). Melalui keterampilan bertanya guru mampu mendeteksi hambatan proses berpikir dikalangan siswa dan dapat memperbaiki serta meningkatkan proses belajar dikalangan siswa (Mulyasa, 2008). Memberikan pertanyaan saat pembelajaran sangat penting dilakukan karena dapat menjaga perhatian dan melibatkan siswa dalam proses pembelajaran (Ragawanti, 2009). Pertanyaan dapat mengarahkan pembelajaran, membangun pengetahuan, meingkatkan kualitas wacana dan komunikasi dalam kelas, mengevaluasi, memantau pemahaman, serta meningkatkan motivasi dan minat belajar dengan membangkitkan rasa ingin tahu siswa (Chin, 2004).

Pertanyaan divergen dapat menimbulkan jawaban yang berbeda dari siswa. Pertanyaan divergen mendorong siswa menganalisis, mensintesis, atau mengevaluasi pengetahuan lalu memperkirakan hasil yang berbeda. Pertanyaan divergen ditujukan untuk merangsang berpikir imajinatif dan kreatif atau menginvestigasi hubungan sebab dan akibat, membangkitkan penyelidikan yang lebih luas (Yuniarti, 2009). Pertanyaan bisa dengan sengaja direkayasa agar pembelajaran berjalan secara maksimal. Sebuah desain petanyaan dapat ditingkatkan agar pembelajaran dapat berjalan efektif. Pertanyaan yang didesain oleh guru harus efektif, seperti menggunakan pertanyaan kualitatif dan pertanyaan analisis. Pertanyaan kualitatif lebih unggul dari pertanyaan kuantitatif untuk memunculkan sebuah argumen. Pertanyaan kualtitatif menimbulkan diskusi mengenai konsep, teori, dan hubungan umum dalam materi pembelajaran. Pertanyaan analisis membutuhkan pengambilan keputusan oleh siswa dan mengarah pada diskusi yang lebih baik serta artikulasi yang lebih berharga daripada pertanyan yang hanya memancing siswa untuk mengingat saja (Beatty, Gerace, Leonard, \& Dufresne, 2008).

Melatih argumentasi siswa juga dapat melalui soal-soal evaluasi yang diberikan guru kepada murid. Selama ini soal-soal yang diberikan lebih menuntut siswa untuk mengahafalkan konsep bukan mengaitkan konsep dengan fenomena-fenomena yang terjadi atau memberikan alasan yang tepat bagi jawaban mereka. Asesmen bentuk essay dipilih karena guru tidak menyediakan alternatif jawaban sehingga siswa harus menguasai banyak pengetahuan yang memungkinkan mereka untuk mengembangkan fakta-fakta dan prinsip-prinsip, untuk mengaturnya secara koheren dan logis, dan kemudian menerapkan ide-ide tersebut. Melalui jawaban yang diberikan pada soal essay, bisa mengetahui tentang bentuk dan kualitas proses pemikiran siswa (Siswanto, 2006)

Soal evaluasi yang baik untuk melatih argumentasi siswa dapat dilakukan dengan cara Argumentative Assessment by Standpoint, Scaffolding and Coding. Model tersebut diawali dengan standpoint yang dirancang sebagai titik awal pengembangan wacana argumentasi yaitu berupa pertanyaan yang kontroversial terkait materi yang sedang dibahas (Eemeren \& Houtlosser, 2007).

\section{METODE}

Penelitian Tindakan Kelas (PTK) dilaksanakan untuk memperbaiki kemampuan argumentasi siswa kelas XI dilakukan selama bulan September hingga bulan Februari, yaitu pada Materi Sistem Gerak dan Sistem Ekskresi. Populasi Penelitian adalah siswa Kelas XI MIPA 4 di salah satu SMA Negeri di Boyolali. Pengambilan sample dilakukan dengan cara purposive sampling sehingga ditentukan kelas XI MIPA 4 sebagai subyek penelitian. Kleas XI MIPA 4 terdiri dari 36 siswa yang terbagi menjadi 22 siswa perempuan dan 14 siswa laki-laki dengan latar yang berbeda-beda.

Penelitian Tindakan Kelas yang dilakukan merupakan kolaboratif antara guru, dosen pembimbing, dan mahasiswa. Guru yang mengajar pada saat penerapan siklus adalah mahasiswa. Pra-siklus dilakukan saat mahasiswa menjalani Program Praktik Lapangan (PPL) di sekolah tersebut. Siklus dilakukan setelah mahasiswa melaksanakan PPL. Mahasiswa PPL telah menempuh mata kuliah kependidikan selama 3 tahun pada fakultas keguruan dan ilmu pendidikan. Guru pamong yang ikut andil telah memiliki pengalaman mengajar lebih dari 15 tahun. Mahasiswa, dosen pembimbing, dan guru pamong secara bersama-sama merumuskan tindakan yang akan diterapkan saat penelitian berlangsung.

Siklus penelitian tindakan yang dilakukan berdasarkan Kemmis, McTaggart, \& Nixon (2014) yang menjelaskan penelitian tindakan merupakan suatu siklus yang berisi tahapan-tahapan, antara lain: merencanakan perubahan, menuangkan rencana dalam suatu tindakan, mengobservasi tindakan yang telah terjadi, dan mereformulasikan rencana ke tindakan berikutnya. Langkah-langkah tersebut kemudian menjadi refleksi pribadi yang membentuk siklus spiral.

Penelitian yang dilakukan diawali dengan mengelompokkan siswa berdasarkan nilai Ulangan Tengah Semester yang sudah mereka tempuh. Pengelompokan berdasarkan nilai KKM yamg ditetapkan pihak sekolah. Siswa yang nilainya berada dibawah nilai KKM dimasukkan dalam kelompok Low achievement dan siswa yang nilainya berada diatas KKM dimasukkan kelompok High achievement. Hal ini bertujuan untuk mengetahui perkembangan siswa dalam setiap kelompok setelah penerapan tindakan.

Langkah-langkah yang diterapkan dalam penelitian adalah tahap perencanan (planning), tahap pelaksanaan tindakan (acting), dan tahap refleksi (reflecting). Tahap perencanaan meliputi kegiatan mempersiapkan instrument pembelajaran, yaitu: RPP, media pembelajaran, Lembar Kerja Siswa, Argumentative Assessment, Lembar Keterlaksanaan Sintak, Lembar Rubrik Teknik Bertanya Guru, Lembar Rubrik respon siswa, Lembar wawancara guru dan lembar wawancara siswa. Tahap pelaksanaan tindakan dilakukan dengan menerapkan model pembelajaran Discovery Learning dipadukan dengan teknik bertanya guru dan argumentative assessment. Tahap pengumpulan data dilakukan melalui instrumen penelitian berupa argumentative assessment. Tahap analisis data dilakukan dengan menganlisis pola teknik pertanyaan guru 
dengan rubrik teknik bertanya guru berupa coding dan menganalisis jawaban siswa menggunakan rubrik level argumentasi berdasarkan Osborne et al. (2004). Tahap refleksi dilakukan menggunakan instrumen penelitian berupa reflective diary yang ditulis guru yang mengajar sehingga dapat menjadi koreksi perbaikan untuk siklus berikutnya.

Teknik pertanyaan yang disiapkan mengarahkan siswa dari tanggapan yang umum menjadi pembahasan topik yang lebih dalam. Strategi tersebut akan membawa siswa kepada 3 domain yang berbeda, yaitu materi pelajaran yang sedang dibahas secara umum, tangapan pribadi, dan realitas eksternal. Materi pelajaran mencakup pengetahuan faktual, konseptual, prosedural yang diperoleh selama pembelajaran. Respon pribadi adalah reaksi peserta didik berdasarkan persepsi dan pengalaman langsung yang berkaitan dengan materi pelajaran. Realitas eksternal adalah hubungan materi pelajaran dengan masyarakat dan disiplin ilmu lainnya (Tofade, Elsner, \& Haines, 2013). Hasil teknik bertanya guru dan respon siswa akan dianalisis dengan sistem koding untuk memahami pola pertanyaan dan respon siswa terhadap pertanyaan tersebut. Sedangkan coding adalah sistem yang mempermudah proses asesmen dan analisis kualitas argumentasi yang berkembang (Clark \& Sampson, 2008; Osborne et al., 2004). Sistem pengkodean memungkinkan perekaman langsung dari apa yang diamati dan menguntungkan peneliti dalam hal waktu dan analisis. (Ary, Jacobs, \& Sorensen, 2010)

Tabel 1. Koding pertanyaan guru yang dikembangkan oleh peneliti

\begin{tabular}{|c|c|c|c|}
\hline $\begin{array}{c}\text { Level Bertanya } \\
\text { Guru }\end{array}$ & Uraian & Rubrik & Koding \\
\hline Level 1 & $\begin{array}{l}\text { Bertanya tentang pemahaman secara umum, } \\
\text { seperti konsep, definisi, teori, untuk mengajak } \\
\text { siswa menyampaikan claim; dengan } \\
\text { menggunakan kata tanya "apa, apakah" }\end{array}$ & $\begin{array}{c}\text { Bertanya tentang definisi } \\
\text { Bertanya tentang teori } \\
\text { Bertanya tentang konsep } \\
\text { Bertanya tentang fakta/kondisi } \\
\text { Bertanya tentang prosedur } \\
\text { Bertanya tentang sikap siswa/metakognisi }\end{array}$ & $\begin{array}{l}\text { Q1-1 } \\
\text { Q1-2 } \\
\text { Q1-3 } \\
\text { Q1-4 } \\
\text { Q1-5 } \\
\text { Q1-6 }\end{array}$ \\
\hline Level 2 & $\begin{array}{c}\text { Bertanya lebih lanjut untuk mengelaborasi } \\
\text { jawaban siswa yang merespon pertanyaan di } \\
\text { level } 1 \text { (general things, konsep, fakta, teori, } \\
\text { prosedur); menggunakan kata tanya } \\
\text { "Bagaimana, mengapa, apa yang terjadi" } \\
\text { (elaboration of claim) }\end{array}$ & $\begin{array}{c}\text { Bertanya dengan meminta penjelasan salah } \\
\text { satu aspek yang disebutkan siswa } \\
\text { Bertanya dengan meminta penjelasan dua } \\
\text { aspek yang disebutkan siswa } \\
\text { Bertanya dengan meminta penjelasan lebih } \\
\text { dari dua aspek yang disebutkan siswa }\end{array}$ & $\begin{array}{l}\text { Q2-1 } \\
\text { Q2-2 } \\
\text { Q2-3 }\end{array}$ \\
\hline Level 3 & $\begin{array}{l}\text { Bertanya atau meminta siswa menjelaskan } \\
\text { pembuktian claimnya, dengan menggunakan } \\
\text { kata tanya, "mengapa, dan bagaimana" } \\
\text { (reasoning and evidence) }\end{array}$ & $\begin{array}{c}\text { Bertanya tentang alasan claim } \\
\text { Bertanya tentang hubungan sebab akibat } \\
\text { Bertanya tentang pembuktian ilmiah } \\
\text { Bertanya tentang aplikasi/contoh nyata }\end{array}$ & $\begin{array}{l}\text { Q3-1 } \\
\text { Q3-2 } \\
\text { Q3-3 } \\
\text { Q3-4 }\end{array}$ \\
\hline Level 4 & $\begin{array}{l}\text { Menyampaikan fakta atau pendapat yang } \\
\text { bertolak belakang dengan jawaban siswa dalam } \\
\text { rangka menimbulkan conflict knowledge atau } \\
\text { rebuttal, dari sumber buku, jurnal, offline } \\
\text { maupun online, sehingga siswa dapat } \\
\text { memperkuat claimnya (rebuttal) }\end{array}$ & $\begin{array}{c}\text { Menyampaikan fakta umum yang } \\
\text { berlawanan } \\
\text { Menyampaikan teori yang berlawanan } \\
\text { Menyampaikan konsep yang berlawanan } \\
\text { Menyampaikan hasil riset yang } \\
\text { berlawanan } \\
\text { Menyampaikan prosedur yang berlawanan }\end{array}$ & $\begin{array}{l}\text { Q4-1 } \\
\text { Q4-2 } \\
\text { Q4-3 } \\
\text { Q4-4 } \\
\text { Q4-5 }\end{array}$ \\
\hline Level 5 & $\begin{array}{c}\text { Bertanya/memberi instruksi kepada siswa untuk } \\
\text { menanggapi rebuttal atau counter claim } \\
\text { counter rebuttal/counter claim) }\end{array}$ & $\begin{array}{l}\text { Bertanya/memberi instruksi umum (setuju } \\
\text { atau tidak setuju) } \\
\text { Bertanya/memberi instruksi detil (alasan } \\
\text { membantah jawaban) }\end{array}$ & $\begin{array}{l}\text { Q5-1 } \\
\text { Q5-2 }\end{array}$ \\
\hline
\end{tabular}

Tabel 2. Koding pertanyaan guru yang dikembangkan oleh peneliti

\begin{tabular}{cccc}
\hline Level argumentasi & Uraian & Rubrik & Koding \\
\hline Level 1 & Menjawab tentang pemahaman & Menyampaikan tentang definisi & A1-1 \\
& secara umum, seperti konsep, & Menyampaikan tentang teori & A1-2 \\
& definisi, teori. & Menyampaikan tentang konsep & A1-3 \\
& & Menyampaikan tentang fakta/kondisi & A1-4 \\
& & Menyampaikan tentang prosedur & A1-5 \\
Level 2 & & Menyampaikan tentang sikap /metakognisi & A1-6 \\
& & Menyampaikan penjelasan salah satu aspek & A2-1 \\
\hline
\end{tabular}




\begin{tabular}{|c|c|c|c|}
\hline Level argumentasi & Uraian & Rubrik & Koding \\
\hline & $\begin{array}{l}\text { Menyampaikan jawaban lebih } \\
\text { lanjut untuk mengelaborasi } \\
\text { general things, konsep, fakta, } \\
\text { teori, prosedur. }\end{array}$ & Menyampaikan penjelasan dua aspek & A2-2 \\
\hline & & Menyampaikan penjelasan lebih dari dua aspek & A2-3 \\
\hline \multirow[t]{4}{*}{ Level 3} & Menjelaskan pembuktian & Menyampaikan tentang alasan claim & A3-1 \\
\hline & claimnya & Menyampaikan tentang hubungan sebab akibat & A3-2 \\
\hline & & Menyampaikan tentang pembuktian ilmiah & A3-3 \\
\hline & & Menyampaikan tentang aplikasi/contoh nyata & A3-4 \\
\hline \multirow[t]{5}{*}{ Level 4} & Menyampaikan fakta atau & Menyampaikan fakta umum yang berlawanan & A4-1 \\
\hline & pendapat yang bertolak belakang & Menyampaikan teori yang berlawanan & A4-2 \\
\hline & maupun online, sehingga siswa & Menyampaikan konsep yang berlawanan & A4-3 \\
\hline & dapat memperkuat claimnya & Menyampaikan hasil riset yang berlawanan & A4-4 \\
\hline & (rebuttal) & Menyampaikan prosedur yang berlawanan & A4-5 \\
\hline \multirow[t]{2}{*}{ Level 5} & Menanggapi rebuttal atau counter & Menyampaikan pendapat umum (setuju atau tidak setuju) & A5-1 \\
\hline & $\begin{array}{c}\text { claim (counter rebuttal/counter } \\
\text { claim) }\end{array}$ & $\begin{array}{l}\text { Menyampaikan pendapat detil (alasan membantah } \\
\text { jawaban) }\end{array}$ & A5-2 \\
\hline
\end{tabular}

Argumentative assessment yang diberikan berupa soal essay dengan pertanyaan divergen. Soal essay dengan pertanyaan divergen diharapakan siswa mampu mengembangkan pendapat pada jawaban. Pertanyaan divergen bersifat terbuka, memiliki banyak tanggapan, menarik kesimpulan dan mengembangkan multidimensi dalam berpikir dalam perspektif yang berbeda (Döş et al., 2016). Argumentative assessment diharapkan dapat mendorong siswa memberikan jawaban secara luas, tidak terpatok pada materi yang terdapat dari buku saja tapi juga menghubungkannya dengan permasalahan umum sehingga dapat memunculkan suatu argumentasi. Hasil argumentative assessment akan dianalisis dengan rubrik level argumentasi siswa berdasarkan Osborne et al. (2004). Level argumentasi siswa akan diberi skor untuk mendapatkan nilai setiap siswa.

Tabel 3. Penilaian Kualitas Argumentasi dengan Kerangka Kerja (Osborne et al., 2004)

\begin{tabular}{|c|c|}
\hline Level & Kriteria \\
\hline 5 & Argumentasi menyajikan argumen yang diperluas dengan lebih dari satu sanggahan yang jelas \\
\hline 4 & Argumentasi menunjukkan argumen dengan suatu sanggahan yang jelas serta memiliki beberapa claim dan counter claim \\
\hline 3 & $\begin{array}{c}\text { Argumentasi berisi argumen dengan sebuah rangkaian claim atau counter claim dengan data, penjamin, atau pendukung } \\
\text { serta sanggahan yang lemah }\end{array}$ \\
\hline 2 & $\begin{array}{c}\text { Argumentasi berisi argumen dari satu claim melawan claim lain dengan data,penjamin atau pendukung tetapi tidak } \\
\text { mengandung sanggahan }\end{array}$ \\
\hline 1 & $\begin{array}{l}\text { Argumentasi mengandung argumen dengan satu claim sederhana melawan suatu claim yang bertentangan (counter } \\
\text { claim) atau satu claim melawan claim lainnya }\end{array}$ \\
\hline
\end{tabular}

Siklus penelitian akan dihentikan jika siswa telah terlihat mengalami perubahan dan peningkatan dalam kemampuan berargumentasi. Kemampuan berargumentasi dapat dikatakan meningkat jika siswa telah mampu menjawab suatu pertanyaan berdasarkan data atau fakta ilmiah dan disertai alasan yang logis.

\section{HASIL PENELITIAN DAN PEMBAHASAN}

Penelitian diawali dengan mengelompokkan siswa menjadi 2 kelompok, yaitu Low Achievement (nilai dibawah KKM) dan High Achievement (nilai diatas KKM) berdasarkan hasil UTS. Berdasarkan pengelompokan awal, terdapat 14 siswa yang masuk dalam kelompok Low Achievement dan 22 siswa yang masuk dalam kelompok High Achievement. Siswa yang termasuk dalam kelompok Low Achievement adalah siswa 8,10, 11, 14, 16, 17, 20, 22,
24, 28, 30, 32, 33, 34. Siswa yang termasuk dalam kelompok High achievement adalah siswa 1, 2, 3, 4, 5, 6, 7, 9, 12, 13, 15, 18, 19, 21, 23, 25, 27, 29, 31, 35, 36.

Penelitian pratindakan dilakukan pada bulan September hingga Oktober 2016. Penelitian pratindakan dilaksanakan pada materi Sistem Gerak. Selama pratindakan, pembelajaran dilakukan dengan cara ceramah dan diskusi. Guru menerangkan materi pelajaran sambil menampilkan slide Powerpoint dan siswa memperhatikan serta beberapa siswa mencatat.

Berdasarkan reflective diary guru, terlihat siswa masih pasif pada penelitian pratindakan. Siswa masih memberi jawaban serentak, singkat, dan guru tidak melakukan pertanyaan lanjutan. Argumentasi yang disampaikan siswa masih berupa claim. Siswa belum dapat menjawab disertai data atau fakta (evidence) dan alasan yang logis 
(reasoning). Berdasarkan argumentative assessment yang diberikan oleh guru pada pratindakan juga menunjukkan siswa masih banyak yang berada pada level argumentasi terendah.

Guru mulai menerapkan model pembelajaran Discovery Learning dipadukan dengan teknik bertanya guru dan argumentative assessment pada Siklus I. Siklus I membahas sistem ekskresi sub bab Kulit dengan hasil ekskresi berupa keringat. Teknik bertanya guru dicantumkan dalam RPP yang telah dipersiapkan sebelum pembelajaran. Teknik yang telah dibuat bertujuan untuk mengarahkan siswa mampu membangun konsep dan melatihkan siswa untuk memberikan argumentasi selama pembelajaran. Argumentative assessment juga telah disipakan untuk mengukur level argumentasi siswa secara tertulis.

Hasil observasi kemampuan argumetasi adanya perubahan dan perbaikan secara bertahap. Selama pembelajaran Siklus I, terjadi dialog-dialog yang merupakan jawaban-jawaban dari siswa yang dapat dilihat level argumentasinya. Contoh dialog pada Siklus I disajikan pada Tabel 4.

Tabel 4. Contoh dialog saat kegiatan diskusi dan presentasi yang dibuat oleh siswa pada Siklus I

\begin{tabular}{|c|c|c|c|}
\hline Sintak & Subjek & Dialog & Koding \\
\hline \multirow{6}{*}{$\begin{array}{l}\text { Apersepsi dan } \\
\text { Motivasi }\end{array}$} & Guru & Menurut kalian, apakah keringat itu? & Q1-1 \\
\hline & 28 & Cairan yang dikeluarkan oleh tubuh & A1-4 \\
\hline & 7 & hasil dari pembakaran dalam tubuh & A1-2 \\
\hline & Guru & Bagaimanakah sifat dari keringat menurut kalian? & Q2-1 \\
\hline & 36 & keringat dikeluarkan untuk menjaga kelembapan tubuh & A1-2 \\
\hline & 1 & keringat biasanya berbau dan rasanya asin & A1-4 \\
\hline \multirow{13}{*}{ Hypotesis testing } & 7 & $\begin{array}{c}\text { keringat sering dihubungkan dengan salah satu cara mengurangi lemak } \\
\text { dalam tubuh }\end{array}$ & A1-2 \\
\hline & 29 & keringat biasanya keluar saat kita melakukan aktivitas berat & A1-4 \\
\hline & 9 & keringat biasanya menimbulkan noda kuning pada baju putih & A1-4 \\
\hline & Guru & Mengapa kamu dapat menghubungkannya dengan tawas? & Q4-1 \\
\hline & & $\begin{array}{l}\text { Karena saya pernah baca kalau dulu sebelum ada deodorant pakainya } \\
\text { bubuk putih tawas untuk menghilangkan bau badan dan sepertinya lebih }\end{array}$ & A4-2 \\
\hline & 1 & aman dibandingkan dengan deodorant & \\
\hline & Guru & $\begin{array}{l}\text { Adakah pendapat atau tanggapan dari pertanyaan dan pernyataan teman } \\
\text { kalian? }\end{array}$ & Q5-1 \\
\hline & & $\begin{array}{l}\text { Iya, bu. Saya pernah baca di internet kalau tawas bisa mencegah bau } \\
\text { badan, selain itu tidak menimbulkan efek ketiak menghitam dan noda }\end{array}$ & A4-2 \\
\hline & 22 & kuning pada baju. & \\
\hline & & Iya bu, saya tidak memakai deodorant buktinya juga tidak timbul noda & A4-1 \\
\hline & 8 & kuning di baju saya & \\
\hline & Guru & $\begin{array}{c}\text { Setelah kamu memakai seragammu, apa yang kamu lakukan sehigga tidak } \\
\text { timbul noda kuning? }\end{array}$ & Q1-6 \\
\hline & 8 & Ya langsung dicuci, bu. & A1-5 \\
\hline
\end{tabular}

Tabel 4., merupakan contoh dialog pertanyaan, jawaban dan sangahan dari siswa pada Siklus I dan level argumentasinya. Teknik pertanyaan yang disiapkan oleh guru juga dianalisis untuk dijadikan refleksi pembelajaran. Berdasarkan rubrik pertanyaan guru, pada Siklus I guru menyampaikan pertanyaan tipe Q1-1 pada apersepsi, yaitu pertanyaan tentang definisi umum atau pandangan umum siswa mengenai keringat. Pertanyaan tipe Q2-1 disampaikan oleh guru pada saat sintaks motivasi, yaitu meminta penjelasan lebih lanjut kepada siswa tentang salah satu aspek saja mengenai keringat. Seharusnya guru mampu mengembangkan pertanyaan mengenai aspek lain tentang keringat. Pertanyaan tipe Q4-1 disampaikan guru pada siktaks hypothesis testing, yaitu meminta siswa menyampaikan fakta umum yang berlawanan dengan penggunaan tawas sebagai pengganti deodorant. Pertanyaan tipe Q5-1 disampaikan guru pada hypothesis testing juga, yaitu bertanya apakah siswa setuju atau tidak dengan pendapat temannya. Pada Siklus I siswa mendiskusikan masalah keringat yang menimbulkan noda kuning pada baju. Siswa juga mendiskusikan apakah pemakaian tawas lebih aman dibandingkan dengan deodorant. Jawaban yang disampaikan oleh siswa juga beragam. Banyak siswa yang menjawab dengan tipe A1-4 yang menyebutkan claim berdasarkan fakta terkait materi. Jawaban tipe A1-2 juga disampaikan siswa berupa klaim berdasarkan teori. Siswa juga mampu menyampaikan tipe jawaban A4-1, yaitu menyampaikan fakta umum yang berlawanan; jawaban tipe A4-2, yaitu menyampaikan teori yang berlawanan; dan jawaban tipe A1-5, yaitu menyampaikan claim berupa prosedur. Siswa yang terlibat dalam dialog sebanyak 8 siswa, 2 diantaranya adalah siswa yang masuk dalam Low achievement, yaitu siswa 8 dan 28 . Berdasarkan jawaban yang disampaikan siswa pada Siklus I masih dinilai kurang beragam dan pertanyaan guru seharusnya masih dapat dikembangkan agar mendorong jawaban siswa lebih divergen lagi.

Berdasarkan kegiatan siswa tersebut, sudah menunjukkan peningkatan yang baik dalam berargumentasi dibandingkan dari pratindakan yang menunjukkan mereka hanya pasif dalam pembelajaran, namun berdasarkan hasil argumentative assessment, siswa 
memang sudah menunjukkan perbaikan level argumentasi dari prasiklus tetapi dirasa belum optimal karena dirasa masih kurang beragam. Teknik bertanya guru juga dirasa belum optimal sehingga perlu adanya perubahan pada pembelajaran berikutnya.

Siklus II dilaksanakan pada materi sistem ekskresi dengan sub bab ginjal dengan hasil ekskresi berupa urine. Guru menerapkan pertanyaan divergen di awal pembelajaran untuk memancing siswa berpendapat tentang urine sebagai hasil ekskresi. Siswa menyampaikan pendapat-pendapatnya tentang urine. Dari pendapat siswa mengenai sifat, ciri, faktor, proses pembentukan urine dan penyakit yang berhubungan dengan ginjal, guru mengarahkan siswa untuk merumuskan masalah dan hipotesis. Proses awal pembelajaran berjalan cukup lancar dan siswa terlihat cukup antusias. Observer setiap kelompok juga mengamati jika siswa mulai tidak ragu melakukan interaksi bertukar pendapat dengan teman kolompoknya. Contoh kegiatan pada siklus II terdapat pada Tabel 5 .

Tabel 5. Contoh dialog saat kegiatan diskusi dan presentasi yang dibuat oleh siswa pada Siklus II

\begin{tabular}{|c|c|c|c|}
\hline Sintak & Subjek & Dialog & koding \\
\hline \multirow{2}{*}{$\begin{array}{l}\text { Apersep } \\
\text { si dan }\end{array}$} & Guru & Apakah yang terdapat di pikiran kalian tentang urine & Q1-3 \\
\hline & 17 & Bau pesing & A1-4 \\
\hline Motivas & 7 & Warnanya kuning & A1-4 \\
\hline \multirow[t]{11}{*}{$\mathrm{i}$} & 9 & Kadang bau obat kalau habis minum obat & A1-4 \\
\hline & 3 & Kalau banyak minum pasti nanti ingin kencing & A1-4 \\
\hline & 30 & Kalau terlalu banyak tertawa juga rasanya ingin kencing, bu & A1-4 \\
\hline & 18 & Kalau udaranya dingin juga ingin kencing terus & A1-4 \\
\hline & Guru & Bagaimanakah warna urine kalian hari ini? & Q1-4 \\
\hline & 1 & Kuning bening, bu & A1-4 \\
\hline & 19 & Bening, bu & A1-4 \\
\hline & 31 & Saya kadang agak gelap oranye, bu & A1-4 \\
\hline & Guru & Nah, kira-kira apakah yang menyebabkan warna urine dapat berbeda-beda? & Q3-2 \\
\hline & 18 & Ada bilirubin yang menyebabkan warna kuning & A3-2 \\
\hline & 1 & Karena kurang minum, bu & A3-2 \\
\hline \multirow[t]{6}{*}{$\begin{array}{l}\text { Hypotes } \\
\quad \text { is } \\
\text { testing }\end{array}$} & 28 & $\begin{array}{l}\text { Gangguan pada glumerolus dapat menyebabkan gagal ginjal karena glomerulus berfungsi } \\
\text { untuk menyaring darah kalau glomerulus tidak befungsi dengan baik ya nanti akan }\end{array}$ & A3-3 \\
\hline & 17 & $\begin{array}{c}\text { Penyerapan kalsium dibantu oleh ginjal. Menurut prosesnya, kalsium dalam darah akan } \\
\text { disaring dan diserap oleh ginjal. }\end{array}$ & A1-2 \\
\hline & 28 & $\begin{array}{l}\text { Setahu saya dari informasi yang pernah saya dapat, batu ginjal disebabkan karena garam- } \\
\text { garam mineral yang mengendap }\end{array}$ & A3-2 \\
\hline & 28 & $\begin{array}{c}\text { Menurut informasi yang pernah saya terima, gagal ginjal bisa diobati dengan obat-obatan } \\
\text { herbal kalau batu ginjalnya masih kecil, kalau sudah besar pasti ya harus operasi, sama } \\
\text { minum air putih yang banyak }\end{array}$ & A4-5 \\
\hline & Guru & Apakah kalian setuju dengan jawaban teman kalian atau ada yang ingin menambahi? & Q5-1 \\
\hline & 5 & Mungkin harus tanya ke dokter lebih lanjutnya atau mungkin malah bisa cangkok ginjal & A5-1 \\
\hline
\end{tabular}

Berdasarkan Gambar 4., hasil analisis pertanyaan yang disampaikan oleh guru menunjukkan pertanyaan tipe Q1-3 pada apersepsi, yaitu menanyakan konsep tentang urine. Pertanyaan tipe Q1-4 disampaikan guru pada sintak motivasi, yaitu menanyakan fakta tentang bagaimana warna urine. Pertanyaan tipe Q3-2 disampaikan untuk melanjutkan motivasi untuk memancing siswa lebih lagi untuk menyatakan sebab warna urine berbeda-beda. Pertanyaan tipe Q5-1 disampaikan guru pada hypothesis testing untuk meminta tanggapan persetujuan atau penolakan dari siswa. Gambar 3. menunjukkan bahwa siswa mampu menyampaikan pendapat dalam berbagai level. Jawaban tipe A1-4 masih mendoiminasi pola jawaban siswa, yaitu menyampaikan claim berupa fakta. Jawaan tipe A1-2 juga dilakukan siswa untuk menyampaikan claim berdasarkan teori. Terdapat juga jawaban tipe A3-2 yang menyampaikan pembuktian claim dengan menyatakan sebab akibat. Siswa juga mampu mengutarakan tipe jawaban A4-5 mengenai prosedur yang berlawanan dengan prosedur umum yang biasa dilakukan.
Siswa juga mampu menanggapi pertanyaan guru dengan jawaban A5-1. Hal tersebut dapat menunjukkan bagaimana pemahaman konsep dan seberapa banyak informasi yang sudah diterima siswa mengenai topik yang sedang dibahas sehingga siswa mampu memberikan pendapat sesuai pemahamannya. Berdasarkan dialog yang dilakukan, terdapat 11 siswa yang terlibat dalam dialog pembelajaran dan 3 diantaranya adalah siswa kelompok Low achievement, yaitu siswa 17 , siswa 28 dan siswa 30 . Siswa 17 menjawab 2 kali dan siswa 28 mampu menjawab 3 kali. Jawaban yang disampaikan oleh siswa 28 termasuk jawaban-jawaban yang memiliki level argumentasi yang cukup baik dan sesuai dengan konsep serta alasan yang logis walaupun siswa tersebut masuk dalam kelompok Low achievement. Penelitian akan dilanjutkan untuk mengoptimalkan kemampuan siswa dalam berargumentasi.

Siklus III perlu dilaksanakan agar lebih optimal untuk memperbaiki kemampuan argumentasi siswa. Siklus III dilaksanakan pada materi sistem ekskresi dengan sub bab Hati dan Paru-paru. Guru menggabungkan kedua sub 
bab tersebut karena siswa telah mempelajari pada materi sistem pencernaan dan sistem pernapasan. Kegiatan pembelajaran berjalan cukup lancar karena siswa merasa sudah pernah mendapatkan pelajaran tentang materi tersebut. Contoh kegiatan pada siklus III terdapat pada Tabel 6 .

Tabel 6. Contoh dialog saat kegiatan diskusi dan presentasi yang dibuat oleh siswa pada Siklus III

\begin{tabular}{|c|c|c|c|}
\hline Sintak & Subyek & Dialog & koding \\
\hline \multirow{12}{*}{$\begin{array}{l}\text { Aperseps } \\
\text { i dan } \\
\text { motivasi }\end{array}$} & Guru & Apakah ada vang pernah melihat bavi yang menderita penvakit kuning? & Q1-4 \\
\hline & 16 & Pernah, bu, di televisi & A1-4 \\
\hline & Guru & Apakah yang menyebabkan bayi tersebut kulitnya berwarna kuning? & Q3-2 \\
\hline & 3 & Karena ada gangguan pada hati & A3-2 \\
\hline & Guru & Apakah hubungannya warna kuning tersebut dengan hati? & Q3-2 \\
\hline & 6 & $\begin{array}{c}\text { Warna kuning disebabkan karena bilirubin yang diproduksi di hati masuk ke aliran } \\
\text { darah }\end{array}$ & A3-2 \\
\hline & Guru & $\begin{array}{l}\text { Lalu, jika kalian berada ditempat yang sempit tetapi berisi banyak orang, apakah yang } \\
\text { kalian rasakan? }\end{array}$ & Q1-4 \\
\hline & 10 & Sesak napas, bu & A1-4 \\
\hline & 23 & Sumuk (panas) & A1-4 \\
\hline & Guru & Mengapa bisa demikian? & Q3-2 \\
\hline & 5 & Tidak ada udara yang masuk. & A3-2 \\
\hline & 19 & $\begin{array}{c}\text { Berebut oksigen, bu. Kan kita butuh oksigen tapi semuanya mengeluarkan } \\
\text { karbondioksida jadi sesak. }\end{array}$ & A2-1 \\
\hline
\end{tabular}

\section{Hypothesis testing \\ Ada yang ingin menambahkan jawaban dari teman kalian? \\ Sirosis hati ini dapat terjadi karena virus hepatitis B dan C yang berkelanjutan \\ 21 Kanker hati sebagai komplikasi akhir dari hepatitis kronis karena virus hepatitis B, C, dan hemokromatis. \\ Menurut sumber yang saya baca, Hepatitis dapat ditularkan dengan hubungan seksual, transfuse darah, mengonsumsi makanan atau minuman yang terkontaminasi virus hepatitis jika hanya berjabat tangan, duduk bersama orang hepatitis tanpa melakukan kegiatan-

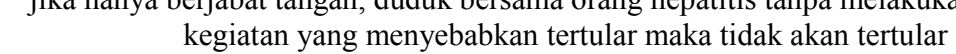

Guru

Apakah ada sanggahan atau pertanyaan?

11 Menurut informasi yang pernah saya terima, alat makan harus disendirikan karena air liur dapat menularkan virus hepatitis

Guru

Ada yang ingin berpendapat? Mengapa harus dilakukan tindakan demikan?

Selain itu, semua baju, handuk juga harus benar-benar dipisahkan, dicuci dengan benar agar virus tidak ditularkan

Berdasarkan kegiatan pada Siklus III, hasil analisis pertanyaan guru menunjukkan semakin banyak tipe pertanyaan yang disampaikan guru. Guru mengajukan pertanyaan tipe Q1-4 pada awal pembelajaran yang menanyakan fakta tentang penyakit kuning, dilanjutkan dengan tipe pertanyaan Q3-2 untuk menghubungkan sebab akibat. Pertanyaan tipe Q1-4 disampaikan kembali untuk menanyakan fakta tentang sesak napas, dilanjutkan dengan tipe Q3-2 untuk menanyakan sebab terjadinya sesak napas. Pertanyaan tipe Q5-1 disampaikan pada hypothesis testing untuk menanyakan pendapat siswa secara umum dan Q5-2 digunakan untuk menyanyakan pendapat siswa secara detail. Berdasarkan jawaban siswa, siswa menyampaikan jawaban dengan level argumentasi yang beragam. Siswa mampu menjawab dengan tipe A1-4, yaitu menyampaikan claim berupa fakta. Jawaban tipe A2-1 digunakan siswa untuk menyampaikan penjelasan salah satu aspek terkait materi. Jawaban tipe A3-2 disampaikan siswa untuk menghubungkan sebab akibat. Jawaban tipe A3-3 disampaikan siswa untuk membuktikan klaimnya dengan bukti ilmiah. Jawaban tipe A4-5 disampaikan siswa untuk menyampaikan pendapat berupa prosedur lain untuk 
memperkuat claim. Terdapat 14 siswa yang terlibat dalam dialog siklus III dan 4 diantaranya adalah kelompok Low achievement, yaitu siswa 11, siswa 16, siswa 28 dan siswa 32. Semakin banyak jumlah siswa yang terlibat dalam mengemukakan pendapat saat pembelajaran. Siswa yang termasuk dalam kelompok Low achievement juga semakin menunjukan keikutsertaannya dalam dialog pembelajaran. Hal tersebut menunjukkan perubahan dan peningkatan kemampuan argumentasi siswa karena sudah mampu menjawab dengan berbagai tipe level argumentasi.

Berdasarkan data argumentative assessment yang dilakukan pada setiap siklus diperoleh hasil berupa kemampuan level argumentasi siswa secara tertulis. Perubahan kemampuan argumentasi siswa kelompok Low achievement dan High achievement disajikan pada Tabel 6 dan Tabel 7.

Tabel 7. Perubahan kemampuan argumentasi siswa kelompok LA setiap siklus

\begin{tabular}{cccc}
\hline Tindakan & Pengukuran & Skor $<60$ & Skor 60 \\
\hline \multirow{2}{*}{ Prasiklus } & Jumlah siswa & 36 & 0 \\
& Nomor siswa & - & - \\
\multirow{2}{*}{ Siklus I } & Jumlah siswa & 4 & 10 \\
& Nomor siswa & $16,22,30,33$ & $8,10,11,14,17,20,24,28,32,34$ \\
\multirow{2}{*}{ Siklus II } & Jumlah siswa & 8 & 6 \\
& Nomor siswa & $11,14,16,22,24,30,33,34$ & $8,10,17,20,28,32$ \\
\multirow{2}{*}{ Siklus III } & Jumlah siswa & 3 & 11 \\
& Nomor siswa & $16,32,34$ & $8,10,11,14,16,17,20,22,24,28,30,32,33,34$ \\
\hline
\end{tabular}

Hasil perbandingan setiap siklus menunjukkan kebergaman skor argumentasi setiap siklus yang diperoleh siswa kelompok LA. Siswa 8, 10, 17, 20, 28 mengalami perubahan skor argumentasi dan hasil yang sama pada setiap siklus, yaitu memperoleh skor 60 secara terusmenerus, sedangkan siswa 11, 14, 24, 32, 33, 34 mengalami perubahan skor argumentasi secara fluktuatif, dan siswa 16 , 22, 30 mengalami peningkatan skor argumentasi secara bertahap. Pada akhir siklus hanya tiga siswa yang masih memperoleh skor kurang dari 60 .

Hasil argumentative assessment dihubungkan dengan dialog interaksi yang terjadi pada setiap silkus. Siswa 28 terlihat paling menonjol walaupun termasuk dalam kelompok LA tetapi cukup aktif dalam pembelajaran. Siswa 28 mampu mengemukakan jawaban argumentasi pada setiap siklus dan menunjukan skor argumentative assessment yang perubahannya mampu menyamai siswasiswa kelompok HA. Hal ini menunjukan bahwa terdapat siswa yang awalnya mempunyai skor rendah dalam hasil belajar sebelum diterapkan tindakan mampu berperan aktif dan mengembangkan konsep dengan cara berargumentasi setelah diterapkannya tindakan. Berdasarkan perbandingan setiap siklus menunjukkan bahwa hanya siswa 16 yang belum mencapai level 3. Secara keseluruhan siswa kelompok LA sudah mampu mencapai level 3 argumentasi.

Tabel 4.8 Perubahan kemampuan argumentasi siswa kelompok HA setiap siklus

\begin{tabular}{cccc}
\hline Tindakan & Pengukuran & Skor $<\mathbf{6 0}$ & Skor 60 \\
\hline Prasiklus & Jumlah siswa & 36 & 0 \\
& $\begin{array}{l}\text { Nomor siswa } \\
\text { Jumlah siswa }\end{array}$ & 2 & 20 \\
Siklus I & Nomor siswa & 4,6 & $1,2,3,5,7,9,12,13,15,18,19,21,23,25,26,27,29,31$, \\
& Jumlah siswa & 4 & 35,36 \\
Siklus II & Nomor siswa & $25,26,27,36$ & 18 \\
& Jumlah siswa & 1 & $1,2,3,4,5,6,79,12,13,15,18,19,21,23,29,31,35$ \\
Siklus III & Nomor siswa & 6 & 21 \\
& & & $1,2,3,4,5,7,9,12,13,15,18,19,21,23,25,26,27,29,3$ \\
\end{tabular}

Hasil perbandingan setiap siklus menunjukkan hasil argumentative assessment pada kelompok siswa HA di setiap siklus. Siswa mempunyai skor argumentasi yang beragam saat Pra-siklus tetapi masih pada level 1 dan 2 saja, skor tidak mencapai 60. Siswa menunjukkan peningkatan yang beragam pada setiap siklus. Siswa 1, 2, $3,5,9,12,13,15,18,19,21,23,31$ dan 35 mengalami peningkatan skor argumentasi dari Pra-siklus dan memperoleh skor 60 secara berturut-turut. Siswa 4 mengalami peningkatan skor argumentasi secara bertahap. Siswa 6, 25, 26, 27, 36 mengalami perubahan skor argumentasi secara fluktuatif. Sejumlah 21 siswa kelompok HA sudah mampu mencapai skor 60. Terdapat 32 siswa diantara 36 siswa dalam kelas sudah mencapai skor 60 , 
sedangkan 4 siswa masih memperoleh skor kurang dari 60 . Secara keseluruhan siswa sudah mampu mengemukakan jawaban disertai dengan evidence dan reasoning atau pada level 3 jika diukur berdasarkan kerangka kerja level argumentasi dari Osborne et al. (2004).

Tabel 9 Perubahan kemampuan argumentasi siswa kelompok LA

\begin{tabular}{ccccc}
\hline Variabel & Prasiklus & $\begin{array}{c}\text { Siklus } \\
\text { I }\end{array}$ & $\begin{array}{c}\text { Siklus } \\
\text { II }\end{array}$ & $\begin{array}{c}\text { Siklus } \\
\text { III }\end{array}$ \\
\hline Mean & 29.1 & 54.3 & 54.0 & 58.6 \\
Median & 27.5 & 60.0 & 52.0 & 60.0 \\
Modus & 27.5 & 60.0 & 60.0 & 60.0 \\
$\begin{array}{c}\text { Nilai } \\
\text { tertinggi }\end{array}$ & 40.0 & 60.0 & 60.0 & 60.0 \\
$\begin{array}{c}\text { Nilai } \\
\text { terendah }\end{array}$ & 25.0 & 32.0 & 40.0 & 50.0 \\
$\begin{array}{c}\text { Standar } \\
\text { deviasi }\end{array}$ & 4.1 & 11.1 & 6.2 & 3.1 \\
\hline
\end{tabular}

Tabel 10 Perubahan kemampuan argumentasi siswa kelompok HA

\begin{tabular}{ccccc}
\hline Variabel & Prasiklus & $\begin{array}{c}\text { Siklus } \\
\text { I }\end{array}$ & $\begin{array}{c}\text { Siklus } \\
\text { II }\end{array}$ & $\begin{array}{c}\text { Siklus } \\
\text { III }\end{array}$ \\
\hline Mean & 32.7 & 60.0 & 58.0 & 60.0 \\
Median & 30.0 & 60.0 & 60.0 & 60.0 \\
Modus & 30.0 & 60.0 & 60.0 & 60.0 \\
$\begin{array}{c}\text { Nilai } \\
\text { tertinggi }\end{array}$ & 50.0 & 60.0 & 60.0 & 60.0 \\
$\begin{array}{c}\text { Nilai } \\
\text { terendah }\end{array}$ & 25.0 & 60.0 & 48.0 & 60.0 \\
$\begin{array}{c}\text { Standar } \\
\text { deviasi }\end{array}$ & 6.8 & 4.9 & 3.8 & 2.1 \\
\hline
\end{tabular}

Berdasarkan Tabel 4.16 dan Tabel 4.17., rata-rata kelompok LA dan HA mengalami perubahan yang fluktuatif. Pada siklus I hingga siklus III terlihat siswa sudah banyak yang mendapatkan skor 60 . Nilai terendah kelompok LA mengalami peningkatan setiap siklus. Pada akhir siklus, sebaran nilai kelompok LA sebesar 3,1 dan kelompok HA sebesar 2,1. Nilai sebaran tersebut menunjukkan jika skor yang dicapai siswa sudah hampir seragam. Tidak terjadi perbedaan skor yang terlalu signifikan dalam kelompok.

Penelitian tindakan kelas yang bertujuan mengubah dan meningkatkan kemampuan argumentasi siswa dianggap cukup dilakukan hingga siklus III. Siswa dianggap sudah menunjukkan peningkatan kemampuan argumentasi dari pratindakan. Hal tersebut dtunjukkan dari data hasil observasi setiap siklus yang menunjukkan bahwa siswa sudah mampu memberikan claim, evidence dan reasoning saat pembelajaran dengan bantuan guru. Skor argumentasi siswa sudah menunjukkan peningkatan.

Penelitian tindakan kelas yang dilakukan membuktikan bahwa teknik bertanya guru dan argumentative assessment mampu mengubah dan memperbaiki kemampuan argumentasi siswa secara bertahap. Siswa yang awalnya hanya mampu menyampaikan claim pada pratindakan sudah mampu menyampaikan pendapat dengan data penjamin (evidence) dan alasan yang logis (reasoning) setelah penerapan tindakan. Penerapan teknik bertanya guru dalam pembelajaran dapat mendorong siswa untuk terbiasa dalam menyampaikan pendapat saat pembelajaran. Teknik bertanya yang diterapkan juga secara bertahap, yaitu diawali dengan pertanyaan secara umum ke pertanyaan khusus atau lebih detail.

Hal tersebut juga membantu siswa untuk membangun konsep dalam pembelajaran. Nussbaum, Sinatra, \& Poliquin (2008) menyatakan bahwa instruksi untuk menyampaikan argumentasi dapat membantu siswa mengubah konsepsi mereka dalam pembelajaran. Acar (2008) menemukan bahwa pengembangan keterampilan menyampaikan argumentasi lebih banyak terkait dengan pengembangan pengetahuan konseptual. Teori tersebut terbukti dalam penelitian, terlihat siswa Low achievement juga menunjukkan peningkatan dalam skor argumentative assessment. Peningkatan tersebut menunjukkan bahwa argumentasi juga mampu mengembangkan konsep yang diterima siswa.

Argumentative assessment yang diberikan juga mampu melatih siswa untuk memberikan evidence dan reasoning yang tepat dalam menjawab soal-soal yang diberikan. Soal evaluasi yang diberikan bukan hanya hafalan konsep tetapi juga memancing siswa berpikir lebih luas lagi. Siswa dapat memberikan pendapat berdasarkan fakta, teori, dan konsep yang telah mereka terima untuk mendukung jawaban. Siswa tidak terpatok dari buku saja tetapi dapat menghubungkan dengan pengalaman mereka didukung dengan bukti ilmiah dan alasan yang logis sehingga dapat menghasilkan sebuah argumen.

Hasil akhir penelitian sudah mampu menunjukkan siswa mengalami perubahan dan peningkatan kemampuan argumentasi secara lisan maupun tertulis. Hal ini sesuai dengan (Mulyasa, 2008).yang menyatakan bahwa keterampilan bertanya guru tidak terpisahkan dalam rangka meningkatkan kualitas proses dan hasil pembelajaran, yang sekaligus merupakan bagian dari keberhasilan dalam pengelolaan instruksional dan pengelolaan kelas. Hasil penelitian juga sesuai dengan Clark (2008) yang menyatakan bahwa dengan penggunaan assessment dengan pertanyaan yang terbuka dapat membantu siswa mengeksplorasi pengetahuannya dengan memberikan umpan balik berupa pendapat.

\section{SIMPULAN DAN SARAN}

Kemampuan argumentasi siswa kelompok LA dan HA sebelum penerapan teknik bertanya guru dan argumentative assessment hanya mencapai level 1 . Penerapan teknik skenario bertanya guru dan argumentative assessment mampu mengubah kemampuan argumentasi kelompok LA dan HA. Data kemampuan argumentasi siswa selama pembelajaran diperoleh melalui observasi kelas dan hasil evaluasi menngunakan argumentative assessment. Data kemampuan argumentasi lisan dan argumentasi tertulis dianalisis menggunakan kerangka kerja Osborne et al. (2004) menunjukkan adanya perubahan dan peningkatan kemampuan argumentasi 
siswa. Kemampuan argumentasi siswa setelah penerapan tindakan mengalami perubahan dan peningkatan. Perubahan yang ditunjukkan adalah siswa sudah mampu mencapai level 3, yaitu memberikan data penjamin dan alasan jika menjawab pertanyaan, bukan hanya menyatakan claim. Secara umum, hasil menunjukkan peningkatan jika dibandingkan dengan sebelum dilakukan tindakan.

Saran yang dapat diberikan dari peneliti adalah penggunaan model pembelajaran dengan teknik bertanya guru dan argumentative assessment untuk mendapatkan kemampuan argumentasi siswa yang lebih baik. Penelitian ini juga dapat dijadikan sebagai referensi untuk penelitian yang berkaitan dengan proses argumentasi siswa dan penelitian berbasis teknik bertanya dan assessment.

\section{DAFTAR PUSTAKA}

Acar, Ö. (2008). Argumentation Skills and Conceptual Knowledge of Undergraduate Students in a Physics by Inquiry Class. The Ohio State University.

Alexiandre, J., \& Erduran, S. (2008). Argumentation in science education: Perspective from classroom-based research. Dordrect, Netherlands: Springer.

Ary, D., Jacobs, L. C., \& Sorensen, C. (2010). Introduction to Research in Education (8th ed.). Canada: Wadsworth Cengage Learning.

Beatty, I. D., Gerace, W. J., Leonard, W. J., \& Dufresne, R. J. (2008). Designing Effective Questions for Classroom Response System Teaching.

Bell, P., \& Linn, M. C. (2000). Scientific Arguments as Learning Artifacts : Designing for Learning from the web with KIE. International Journal of Science Education, 22, 797-817.

Chin, C. (2004). Classrooms Students' Questions : Fostering a Culture of Inquisitiveness in Science Classrooms. School Science Review, 86(314), 107112.

Clark, D. B., \& Sampson, V. (2008). Assessment of the Ways Students Generate Arguments in Science Education: Current Perspectives and Recommendations for Future. Wiley Periodeicals, Inc. Sci Ed, 92, 447-472. http://doi.org/10.1002/sce.20276

Clark, I. (2008). Assessment is for Learning: Formative Assessment and Positive Learning Interactions. Florida Journal of Educational Administration \& Policy, 2(1), 1-16.

Döş, B., Bay, E., Aslansoy, C., Tiryaki, B., Çetin, N., \& Duman, C. (2016). An analysis of teachers questioning strategies. Eucation Research and
Reviews,
11(22),
2065-2078.

http://doi.org/10.5897/ERR2016.3014

Eemeren, F. H. Van, \& Houtlosser, P. (2007). Dialectical Profiles and Indicators of Argumentative Moves. OSSA Conference Archive, 37, 0-17.

Ermasari, G., Subagia, I. W., \& Sudria, I. B. N. (2014). Kemampuan Bertanya Guru IPA dalam Pengelolaan Pembelajaran. E-Journal Program Pascasarjana Universitas Pendidikan Ganesha, 4.

Kaya, E., Erduran, S., \& Cetin, P. S. (2010). High School Students' Perceptions of Argumentation. Procedia Social and Behavioral Sciences, 2, 3971-3975. http://doi.org/10.1016/j.sbspro.2010.03.625

Kemmis, S., McTaggart, R., \& Nixon, R. (2014). The Action Resesarch Planner (ISBN 978-9). Singapore: Springer.

Krajcik, J. S., \& McNeill, K. L. (2011). Assessing Middle School Students' Content Knowledge and Scientific Reasoning Through Written Explanations. University of Michigan .

McNeill, K. L., \& Berland, L. K. (2010). A Learning Progression for Scientific Argumentation: Understanding Student Work and Designing Supportive Instructional Contexts. Journal Science Education. http://doi.org/10.1002/sce.20402

Mulyasa. (2008). Menjadi Guru Profesional menciptakan Pembelajaran Kreatif dan Menyenangkan. Bandung: Remaja Rosdakarya.

Nussbaum, E. M., Sinatra, G. M., \& Poliquin, A. (2008). Role of Epistemic Beliefs and Scientific Argumentation in Science Learning. International Journal of Science Education, 30(15), 1977-1999. http://doi.org/10.1080/09500690701545919

Osborne, J., Erduran, S., \& Simon, S. (2004). Enhancing The Quality of Argument in School Science. Journal of Research in Science Teaching. http://doi.org/10.1002/tea.20035

Ragawanti, D. T. (2009). Questions and Questioning Techniques: A View of Indonesian Students , Preferences.K@ta,11(2),155-170.

Siswanto. (2006). Penggunaan Tes Essay dalam Evaluasi Pembelajaran. Jurnal Pendidikan Akuntansi Indonesia, $V(1), 55-61$.

Tofade, T., Elsner, J., \& Haines, S. T. (2013). Best Practice Strategies for Effective Use of Questions as a Teaching Tool. American Journal of Pharmaceutical Education, 77(7).

Yuniarti, T. (2009). Fungsi dan Pentingnya Pertanyaan dalam Pembelajaran. Prosiding Seminar Nasional Matematika Dan Pendidikan Matematika, 174-184. 